\title{
In Vitro and In Vivo Activity of Fomitopsis Pinicola (Sw. Ex Fr.) Karst Chloroform (Fpkc) Extract Against S180 Tumor Cells
}

\author{
Ye Gao Pan Wang Yaqin Wang Lijie Wu Xiaobing Wang \\ Kun Zhang Quanhong Liu
}

Key Laboratory of Medicinal Resources and Natural Pharmaceutical Chemistry, Ministry of Education, National Engineering Laboratory for Resource Developing of Endangered Chinese Crude Drugs in Northwest of China, College of Life Sciences, Shaanxi Normal University, Xi'an, Shaanxi, China

\section{Key Words}

Fpkc • Apoptosis • Mitochondria • In vivo • In vitro

\begin{abstract}
Background/Aims: Non-toxic fomitopsis is has been traditionally used in folk medicine in many countries for its anti-inflammatory and anti-vascular disease activities. The present study investigates the antitumor effect of Fomitopsis pinicola (Sw. Ex Fr.) Karst chloroform extract (FPKC) on S180 tumor cells in vitro and in vivo and we determined the underlying mechanisms. Methods: HPLC was employed to analyze the constituents of FPKc. In-vitro 3-(4,5-Dimethylthiazol-2-yl)-2,5-diphenyltetrazolium bromide (MTT) assay was performed to quantify the growth inhibition of FPKc; Propidium iodide (PI) exclusion assay and scanning electron microscopy (SEM) were used to observe the damage on the cell membrane and the changes of the cell morphology; Staining with Hoechst 33342/propidium iodide (HO/PI) and the application of the Annexin V-FITC/PI analysis permitted to observe the cell death triggered by FPKc; DNA damage and cell cycle arrest were detected by flow cytometry; Rhodamine 123 ( $\mathrm{RH} 123$ ) and Cytochrome $\mathrm{C}$ were used as dyes to investigate the alterations of the mitochondria. In-vivo tumor inhibition and mice survival time were determined. Results: The results of the HPLC assay indicated that FPKC might contain DA (dehydroeburiconic acid), PA (pachymic acid), and ES (ergosterol), at percentages of $0.25 \%, 17.8 \%$, and $10.5 \%$, respectively. Concerning the study of the biological function, the results showed that FPKc exhibited preferential and significant suppression of proliferation on specific cell lines including S180, HL-60, U937, K562, SMMC-7721, and Eca-109 cells, which induced plasma membrane and cell morphology damages, triggering S180 tumor-cells late apoptosis and leading to DNA damage and S phase arrest. Mitochondria were suspected to play a vital role in these changes. In vivo data indicated that FPKc inhibited the solid tumor growth and prolonged the survival time of tumor-bearing mice. Moreover, FPKc provoked only little damage on normal cells in vitro and also on normal tissues in vivo. Conclusion: FPKc inhibited S180 tumor cells growth and prolonged the lifespan of mice. In vitro, we found that FPKc induced S180 tumor cells apoptosis and cell cycle arrest, possibly via the mitochondrial pathway.

(C) 2017 The Author(s)

Published by S. Karger AG, Basel

Xiaobing Wang

College of Life Sciences, Shaanxi Normal University,

and Kun Zhang

Xi'an 710062, Shaanxi, (China)

Tel. +86-029-853 10275; E-Mail wangxiaobing@snnu.edu.cn; zkxian@snnu.edu.cn
\end{abstract}




\section{Cellular Physiology Cell Physiol Biochem 2017;44:2042-2056 \begin{tabular}{l|l|l} 
and Biochemistry & DOI: 10.1159/000485944 & $\begin{array}{l}\text { C } 2017 \text { The Author(s). Published by S. Karger AG, Basel } \\
\text { www.karger.com/cpb }\end{array}$
\end{tabular} \\ Gao et al.: FPKc Extract against S180 Tumor Cells}

\section{Introduction}

Fomitopsis pinicola (Sw. Ex Fr.) Karst (FPK) is a brown-rot fungus and belongs to the Polyporaceae. It grows on coniferous and broad-leaved trees and is widely distributed in Asia and Europe [1]. The fungus FPK is traditionally categorized as Reishi fungus in Far Eastern Asia. In traditional medicine, FPK is used for the treatment of headache, nausea, and liver problems [2]. Moreover, the fruit bodies are used as anti-inflammatory agents [3]. Additionally, studies report that crude extracellular polysaccharides (EPS) produced in aqueous and alkali extracts of FPK present anti-hyperglycemic activity [4].

In the recent years, a growing number of studies are reported on the biological function and chemical analysis of FPK extracts. Concerning the chemical analysis of FPK, it was reported that FPK mainly contains triterpenoids such as ergosterol, ergosterol derivatives, and lanostane triterpenes among others. Besides, studies demonstrated that FPK extracts contained polysaccharides, cerebroside lipids, and volatile substances [4, 5]. Biological activity studies showed that FPK extracts and its principle components have antimicrobial, anticancer, and antioxidant activities [6]. The studies focusing on the anticancer effect was mainly done on ethanol, petrol ether, and ethyl acetate extracts. In example, Ren et al. showed that petrol ether and ethyl acetate extracts of FPK presented cytotoxicity against Hela and SMMC-7721 cell lines [7]. Hung-Tsung Wu from Taiwan demonstrated in vitro and in vivo the anticancer activity of FPK ethanol-extract [8].

We previously investigated the growth inhibition of FPK chloroform and ethanol extracts on SW-480 cells. Our results showed that FPK chloroform extract appeared more effective than FPK ethanol-extract. Thus, in this study, FPKc was chosen as the topic to study. Firstly, we analyzed the chemical constituents by HPLC; secondly, we evaluated the FPKc antitumor effect on S180 tumor cells in vitro and in vivo; finally, the role of mitochondria in the FPKcinduced apoptosis was further elucidated.

\section{Materials and Methods}

Collection and preparation of the fruit-body powder

Fresh FPK was collected in July 2011 from Pingheliang in the south of the QinLing Mountains, Shaanxi province, China (latitude $33^{\circ} 27^{\prime} \mathrm{N}$, longitude $108^{\circ} 30^{\prime} \mathrm{E}$, altitude $2305 \mathrm{~m}$ ). Identification of the plant species identities was validated by Prof. Yaping Xiao. The washed fruit body was air dried in shade at room temperature $\left(25-30{ }^{\circ} \mathrm{C}\right)$ for 3 days, then dehydrated in an incubator at $45^{\circ} \mathrm{C}$ for $12 \mathrm{~h}$. Following the drying process, the fruit body was then powdered by milling, sieved through a fine mesh, and stored at $4{ }^{\circ} \mathrm{C}$ for further use.

\section{Preparation of chloroform extract of FPK}

Dried FPK powder was homogenized in $95 \%$ ethanol $(\mathrm{EtOH}, \mathrm{w} / \mathrm{v})$ at $45^{\circ} \mathrm{C}$, and submitted three times to ultrasonic-assisted extraction (UAE). The ethanol solution was then vacuum filtered and the eluent was concentrated on a rotary evaporator (RE-2000 A; Belong, Shanghai, China). After concentration, the product was freeze-dried (ALPHA1-2, CHRIST, Germany) and then lyophilized. The dried matter (ethanol extract sample) was stored until to use at $-20^{\circ} \mathrm{C}$. The extract was then fractionated with chloroform $\left(\mathrm{CHCl}_{3}\right)$. The chloroform fraction was homogenized in $70 \%$ ethanol and centrifuged at $3000 \mathrm{rpm} / \mathrm{min}$ for $15 \mathrm{~min}$ at $25^{\circ} \mathrm{C}$. The supernatant was filtered on a $0.45 \mathrm{~mm}$ filters and then on a $0.22 \mathrm{~mm}$ filter.

\section{HPLC analysis}

The determinations of the composition of FPKc and contents of ES (ergosterol), PA (Pachymic acid), and dehydroeburicoic acid (DA) were evaluated by HPLC. The LC system consisted of the Shimadzu LC-2010 (Shimadzu Corp., Kyoto, Japan) equipped with a quaternary pump and thermostat column compartment. We used the Shimadzu LC solution software. Separation of the phytochemicals was achieved on a Shimpack VP-ODS C18 column (Shimadzu, $1504.6 \mathrm{~mm}, 5 \mathrm{~mm}$ ). The mobile phase was composed of acetonitrile and water. The gradient elution was $10-100 \%$ acetonitrile $(\mathrm{v} / \mathrm{v})$ at $0-80 \mathrm{~min}$ and then maintaining $100 \%$ acetonitrile $(\mathrm{v} / \mathrm{v})$ at 80-100 min. The column temperature maintained at $40{ }^{\circ} \mathrm{C}$, and the mobile phase flow rate was $1 \mathrm{~mL} / \mathrm{min}$. The detection wavelengths were 254 and $210 \mathrm{~nm}$ and $20 \mu \mathrm{L}$ of sample were injected. 


\section{Cellular Physiology Cell Physiol Biochem 2017;44:2042-2056 \begin{tabular}{ll|l} 
and Biochemistry Published onlıne: December 12, 2017 & $\begin{array}{l}\text { C } 2017 \text { The Author(s). Published by S. Karger AG, Basel } \\
\text { www.karger.com/cpb }\end{array}$ \\
\hline
\end{tabular} \\ Gao et al.: FPKc Extract against S180 Tumor Cells}

\section{Cell cultures}

S180, SMMC-7721, Eca-109, K562, U937 and HL-60 cells were obtained from the cell bank of Chinese Academy of Science, Shanghai, China. All the cell lines were cultured under standard conditions in RPMI-1640 medium containing 10\% FBS, 1\% penicillin-streptomycin (100 U/mL penicillin and $100 \mu \mathrm{g} /$ $\mathrm{mL}$ streptomycin), and $1 \%$ of a L-glutamine solution $(1 \mathrm{mM})$. The cells were sub-cultured every day and incubated at $37^{\circ} \mathrm{C}$ in humidified atmosphere in an incubator containing $5 \% \mathrm{CO}_{2}$.

\section{Cell viability assay of the different cancer cells}

The effects of FPKc on S180, HL-60, K562, U937, SMMC-7721, and Eca-109 cell viability were determined by a conventional MTT reduction assay. Briefly, $100 \mu \mathrm{L}$ of cell suspension were placed in each well of a 96-well culture plate at a density of $1 \times 10^{5}$ cells $/ \mathrm{mL}$ and incubated with various concentrations of FPKc ( 80 and $120 \mu \mathrm{g} / \mathrm{mL}$ ) and a solution of 70\% ethanol was used as the solvent control at 48 and $72 \mathrm{~h}$ ). The treated cells were incubated with a MTT solution and the formazan crystals were dissolved in $100 \mu \mathrm{L}$ of a solution composed of $10 \%$ SDS, 5\% isobutanol, and $0.01 \mathrm{M} \mathrm{HCl}$ solution. Absorbance at $570 \mathrm{~nm}$ was recorded with a microplate reader (Bio-Tek ELX800, USA). The cell viability of FPKc and ES treated samples were then analyzed by comparing the results with the ones of the untreated sample.

\section{In-vitro safety evaluation of FPKC}

Peripheral blood mononuclear cells (PBMCs) and Heart and Umbilical Vein Endothelial cells (HUVE) were used to evaluate the safety of FPKc. The PBMCs were isolated thanks to the lymphocyte separation kit (Applygen Technologies Inc., Beijing, China) following the instructions provided by the company. The viability of the obtained PBMCs was assessed using the trypan blue exclusion test. The results indicated viability above $95 \%$. The HUVE cells were seeded in 96 -well plates $\left(1 \times 10^{5}\right.$ cells $\left./ \mathrm{mL}\right)$. Various concentrations of FPKc $(100,200,300$, and $400 \mu \mathrm{g} / \mathrm{mL})$ were added in each well and the cells were incubated for $48 \mathrm{~h}$. After that, cells viability was evaluated by a MTT assay.

\section{Flow cytometry analysis of the cell membrane integrity}

To monitor the membrane permeability in parallel, a membrane-impermanent dye, propidium iodide (PI), was added. The PI dye enters the cell only if the cell membrane becomes permeable, which is a technique widely used in cell death determination studies of the integrity of plasma membranes. When the dye bounds to nucleic acids, the absorption maximum of PI shifts to $535 \mathrm{~nm}$ and the fluorescence emission maximum appears at $617 \mathrm{~nm}$. Cells were treated with various concentrations of FPKc $(80$ and $120 \mu \mathrm{g} / \mathrm{mL}$ for $24 \mathrm{~h}$. Then, the treated cells were harvested and washed twice with PBS, followed by a staining step with $5 \mu \mathrm{g} / \mathrm{mL}$ of PI for $5 \mathrm{~min}$ in the dark. The samples were then analyzed by flow cytometry (Guava easyCyte 8HT, Millipore, USA). Histograms were analyzed using the FCS Express V3 (De Novo Software).

\section{Scanning electron microscope observation}

After $24 \mathrm{~h}$ following the addition of various concentrations of FPKc (80 and $120 \mu \mathrm{g} / \mathrm{mL}$ ), cells in each group were fixed with $2.5 \%$ glutaraldehyde, washed with PBS, dehydrated by graded alcohol, displaced, dried at the critical point, gold evaporated, and finally observed under a scanning electron microscope (S-3400N, Hitachi, Tokyo, Japan).

\section{Hoechst 33342-PI double staining}

After the addition of various concentrations of FPKc (80 and $120 \mu \mathrm{g} / \mathrm{mL}$ ) for $48 \mathrm{~h}$, cells were collected and washed with PBS. Then, Hoechst 33342 (HO) and PI were added directly to the culture medium at final concentrations of 5 and $3.34 \mu \mathrm{M}$, respectively. After an incubation period of $15 \mathrm{~min}$ at room temperature in the dark, cells were washed three times with PBS and observed by fluorescence microscopy with standard excitation filters (Nikon E-600, Japan).

\section{Apoptosis detection by flow cytometry}

To further confirm the pro-apoptosis effect provoked by FPKc and quantify the apoptosis, cells were monitored via flow cytometry after dual staining with Annexin V-FITC and PI. After addition of 80 and $120 \mu \mathrm{g} / \mathrm{mL}$ of FPKc for $24 \mathrm{~h}$, the S180 cells were harvested and re-suspended in $500 \mu \mathrm{L}$ of binding buffer. The cells were stained with $10 \mu \mathrm{L}$ of Annexin V-FITC and $5 \mu \mathrm{L}$ of PI for 15 min at room temperature in the 


\section{Cellular Physiology Cell Physiol Biochem 2017;44:2042-2056 and Biochemistry Published $\begin{aligned} & \text { DOI: 10.1159/000485944 } \\ & \text { (c) } 2017 \text { The Author(s). Published by S. Karger AG, Basel } \\ & \text { www.karger.com/cpb }\end{aligned}$ \\ Gao et al.: FPKc Extract against S180 Tumor Cells}

dark. The apoptotic index was immediately determined by flow cytometry (Guava easyCyte 8HT, Millipore, Billerica, MA, USA).

\section{DNA fragmentation assay}

An easy and quantitative method to analyze DNA fragmentation is the flow fluorocytometric detection of DNA hypoploidy after adding PI to the dyed cells and permeabilizing them by freeze-thawing [9]. To investigate the potential DNA damage of S180 cells caused by FPKc, we performed oligonucleosomal DNA fragmentation by flow fluorocytometry. Cells were treated with various concentrations of FPKc (80 and $120 \mu \mathrm{g} / \mathrm{mL}$ ) for $24 \mathrm{~h}$, then stained with $5 \mu \mathrm{g} / \mathrm{mL}$ of PI, and finally freeze-thawed for $30 \mathrm{~s}$. Cells were immediately analyzed by flow cytometry.

\section{Analysis of the cell cycle arrest caused by FPKc}

The ratio of cells in the G1, S, and G2/M phases of the cell cycle was determined by quantifying their DNA content. The S180 cells were treated with various concentrations of FPKc (80 and $120 \mu \mathrm{g} / \mathrm{mL}$ ) for $72 \mathrm{~h}$. The cells were then harvested and washed twice with cold PBS containing 1\% BSA. The cells were fixed with $70 \%$ ice-cold ethanol and stored at $4{ }^{\circ} \mathrm{C}$ overnight. The fixed cells were washed twice with cold PBS and incubated with $100 \mu \mathrm{g} / \mathrm{mL}$ RNase A (Sigma, St.Louis, USA) for $30 \mathrm{~min}$ at $37^{\circ} \mathrm{C}$, then stained with $50 \mu \mathrm{g} / \mathrm{mL}$ of PI for 30 min in the dark and then analyzed by flow cytometry (Millipore, USA).

\section{Measurement of the mitochondrial membrane potential}

The changes of the mitochondrial membrane potential (MMP) were assessed by using the fluorescent probe Rhodamine 123 (Rh 123, Sigma, St Louis, USA). The dye Rh123 selectively enters mitochondria without influencing the membrane potential and are retains inside the mitochondria. Once the MMP is lost, Rh123 is subsequently washed out of the cells, leading to the decline of the fluorescence signal. Cells $\left(1 \times 10^{5}\right.$ cells $/ \mathrm{mL}$ ) were incubated with various concentrations of FPKc ( 80 and $120 \mu \mathrm{g} / \mathrm{mL}$ ) for $24 \mathrm{~h}$ and then stained with $2 \mathrm{mg} / \mathrm{mL}$ of Rh123 for 20 min under gentle shaking. After washing with PBS, cells were immediately analyzed by flow cytometry and data was analyzed using the FCS Express software.

\section{Release of cytochrome C induced by FPKC}

Cells in each treatment group were pre-incubated with $0.5 \mathrm{mM} \mathrm{MTG}$ in PBS at $37^{\circ} \mathrm{C}$ for $20 \mathrm{~min}$, fixed in $4 \%$ paraformaldehyde at $4{ }^{\circ} \mathrm{C}$ for $15 \mathrm{~min}$, and subsequently permeabilized with $0.1 \%$ Triton X-100 at $4{ }^{\circ} \mathrm{C}$ for 5 min. Between each step, cells were washed with PBS. After permeation, cells were blocked in goat serum at $37^{\circ} \mathrm{C}$ for one hour and then incubated with anti-cytochrome-c antibodies (Santa Cruz Biotechnology, Santa Cruz, CA, USA) overnight at $4{ }^{\circ} \mathrm{C}$. After washing with PBS, the samples were incubated with a solution of fluorescein isothiocyanate-conjugated secondary antibody. Finally, the cells were observed by fluorescence microscope (Nikon E600, Japan).

\section{In-vivo anticancer effect of FPKC}

The Institute of Cancer Research (ICR) mice (female, 18-22 g body weight) were supplied by the Experimental Animal Center of the Xi'an Jiao Tong University (Xi'an, China). The S180 cells were suspended in an air-saturated PBS solution at a concentration of $1 \times 10^{7}$ cells $/ \mathrm{mL}$. It is well documented that some natural products can prolong the survival time of mice having ascites tumors and inhibit in vivo the growth of solid tumor [10]. In our study, the ICR mice were divided into 2 groups. The first group was inoculated subcutaneously at the left oxter region and was designed for the determination of the inhibition rate after FPKc treatment. The mice of the second group were subjected to an intraperitoneal injection of S180 tumor cells in order to determine the survival time post of the mice after FPKc treatment. All experiments with live animals were carried out with the approval of the University's institutional animal care and use committee.

The mice with solid tumor were further divided into 3 groups. The first group constituted the control group in which the mice were fed with $0.2 \mathrm{~mL}$ of normal saline solution every day. The second group was the CTX (cyclophosphamide, $20 \mathrm{mg} / \mathrm{kg}$ ) group (positive control) in which we injected to the mice a daily dose of $0.2 \mathrm{~mL}$. The third group was the FPKc $(200 \mathrm{mg} / \mathrm{kg})$ group in which the mice were fed with $0.2 \mathrm{~mL}$ of FPKc every day. For FPKc and control groups, mice were pretreated 7 days before tumor implantation, whereas the mice of the CTX group were intraperitoneally treated every two days after tumor implantation. The same treatments were undertaken for the mice with ascites tumor. 
The thymus and spleen were collected from the mice, washed with PBS, and then weighed. The thymus index (TI) and spleen index (SI) were calculated according to the following formulae: TI = thymus weight $(\mathrm{mg}) /$ body weight $(\mathrm{g}) \times 100$; SI = spleen weight $(\mathrm{mg}) /$ body weight $(\mathrm{g}) \times 100$.

\section{Results}

\section{HPLC analysis for FPKC}

The method mentioned above had applied to the determination of FPKc, ES, DA, and PA. As it shown in Fig. 1, at $210 \mathrm{~nm}, \mathrm{PA}$ and ES were detected at 50.86 and $92.514 \mathrm{~min}$, respectively. In Fig. 2, at $254 \mathrm{~nm}$, DA was detected at 58.54 min. Furthermore, the present study, the three compounds were quantified in FPKc. As revealed in Table 1, DA, PA and ES possessed about $2.5 \mu \mathrm{g} / \mathrm{mg}, 35.6 \mu \mathrm{g} / \mathrm{mg}$ and $105 \mu \mathrm{g} / \mathrm{mg}$, respectively.

\section{Cytotoxicity effect of FPKc on different cancer cells}

According to the US estimation from 2013, it is reported that leukemia, liver cancer, and esophageal carcinoma are three of the common causes of death [11]. In order to evaluate the anti-cancer activity of FPKc, different cancer cells including the ones of SMMC-7721, Eca-109, three types of human leukemia cancer (U937, K562 and HL-60), and Sarcoma 180 tumor cells. The cells were treated with two different concentrations of FPKc (80 and $120 \mu \mathrm{g} / \mathrm{mL}$ ) for $48 \mathrm{~h}$ and $72 \mathrm{~h}$. The Table 2 shows the response of the different cancer cell lines towards FPKc. The cell lines, HL-60, U937, and K562, exhibited a strong sensitivity and the $\mathrm{IC}_{50}$ were $45.13,39.07,139.81 \mu \mathrm{g} /$

$\mathrm{ml}$ at $48 \mathrm{~h}$, respectively. In contrast, SMMC-7721 and Eca-109 cell lines were less sensitive towards FPKc than the other cell lines and the $\mathrm{IC}_{50}$ were 320.12 and $209.78 \mu \mathrm{g} / \mathrm{mL}$ after 48 incubation, respectively. In the case of the S180 cells, when the dose of FPKc was $80 \mu \mathrm{g} / \mathrm{mL}$, the cell viability loss was $30.8 \% \pm 0.78 \%$. However, the cell viability loss increased to $49.8 \% \pm 0.68 \%$ (Fig. 3C) when the dose was $120 \mu \mathrm{g} / \mathrm{mL}$. The $\mathrm{IC}_{50}$ for the S180 cells was $104.9 \mu \mathrm{g} / \mathrm{mL}$ at $48 \mathrm{~h}$ (Tab. 2 ). When the incubation time increased from 48 $\mathrm{h}$ to $72 \mathrm{~h}$, the $\mathrm{IC}_{50}$ value decreased, which indicated that FPKc exerted its anticancer function in a time- and dose-dependent manner. We chose 80 and $120 \mu \mathrm{g} / \mathrm{mL}$ as the test concentration during the whole experiment.

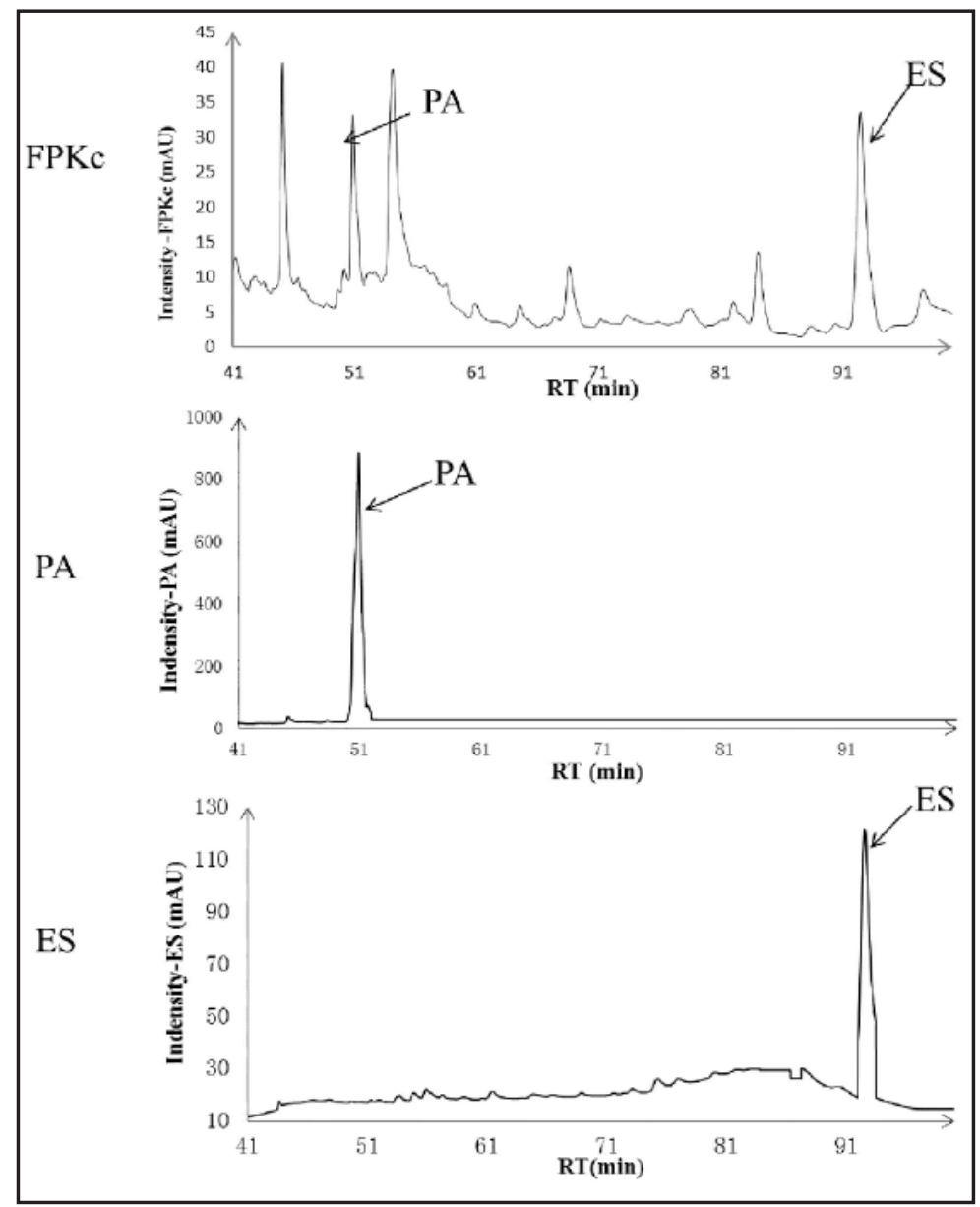

Fig. 1. PA, ES and FPKc were analyzed with HPLC at 210nm. 
In-vitro safety evaluation of FPKC

One of the main advantages to use natural products is their low toxicity towards normal tissues [12].Thus PBMC and HUV-E cells were used to evaluate the safety of FPKc. There was no obvious cytotoxicity effect on PBMC cells even when the concentration of FPKc increased to $380 \mu \mathrm{g} /$ $\mathrm{mL}$ as displayed by the results depicted in Fig. 3A. Moreover, when the dose of FPKc was $400 \mu \mathrm{g} /$ $\mathrm{mL}$, the cell viability of HUV-EC was 86.4 $\pm 0.66 \%$ (Fig. 3B), which was much higher than that of the SMMC-7721 and Eca-109 cells. Both data indicated that FPKc could protect non-malignant cells while performing an anticancer effect.

The results of Fig. 3C illustrates the cytotoxicity of FPKc on the S180 cells, which was much higher than that of normal cells.

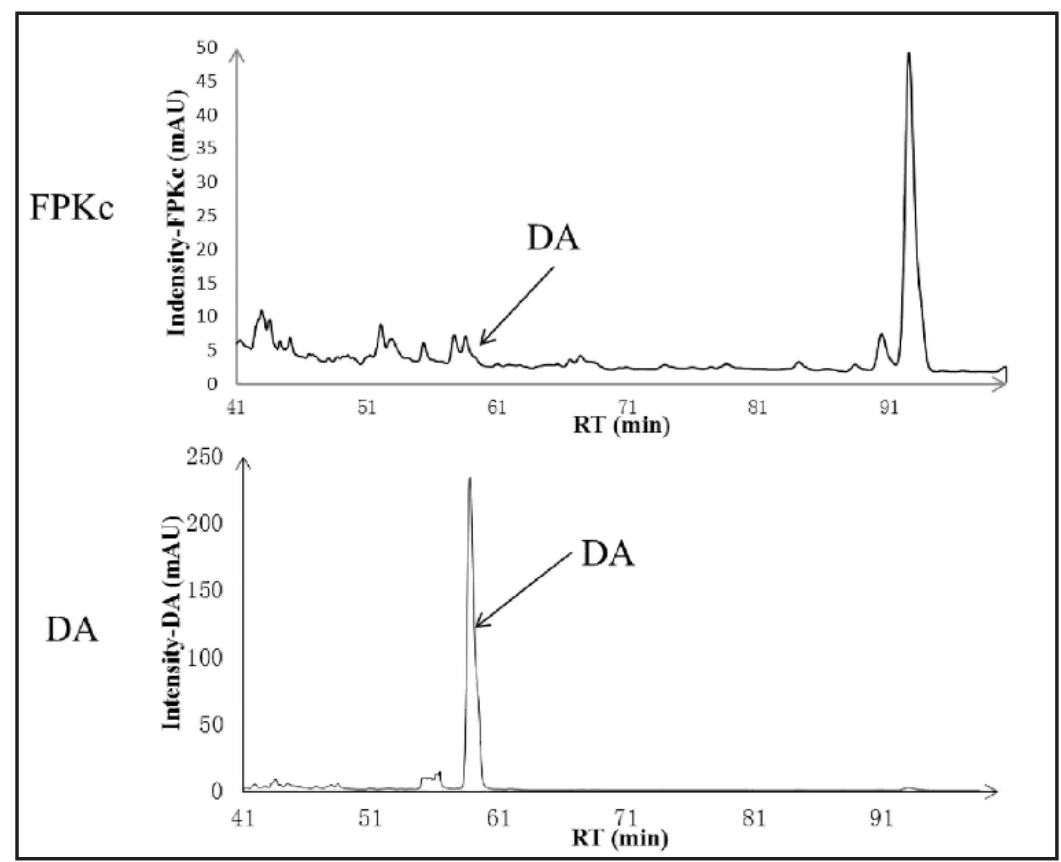

Fig. 2. DA and FPKc were detected with HPLC at 254nm.

Table 1. HPLC analysis of DA, PA and ES

\begin{tabular}{lcc}
\hline Compunds & Content in FPKC $(\mu \mathrm{g} / \mathrm{mg})$ & RT $(\mathrm{min})$ \\
\hline Dehydroeburicoic acid (DA) & 2.5 & 58.54 \\
Pachymic acid (PA) & 35.60 & 50.86 \\
Ergosterol (ES) & 105.00 & 92.51 \\
\hline
\end{tabular}

Table 2. Different cancer cells were chosen to evaluate the anticancer effect of FPKc

\begin{tabular}{lccc}
\hline Cell line & Cell density (cell/mL) & $\begin{array}{c}\text { IC } 50 \text { at } 48 \mathrm{~h} \\
(\mu \mathrm{g} / \mathrm{mL})\end{array}$ & $\begin{array}{c}\text { IC } 50 \text { at } 72 \mathrm{~h} \\
(\mu \mathrm{g} / \mathrm{mL})\end{array}$ \\
\hline S180 & $1 \times 10^{5}$ & 104.9 & 36.21 \\
K562 & $1 \times 10^{5}$ & 139.81 & 98.8 \\
HL-60 & $1 \times 10^{5}$ & 45.1 & 40.99 \\
U937 & $1 \times 10^{5}$ & 39.07 & 34.85 \\
SMMC- & $1 \times 10^{5}$ & 320.12 & 246.20 \\
7721 & $1 \times 10^{5}$ & 209.78 & 169.73 \\
Eca-109 & & & \\
\hline
\end{tabular}

\section{Cell membrane integrity measurement}

The PI staining combined with flow cytometry was used to evaluate the FPKc-induced damage on the cell membranes. After incubation with FPKc for $24 \mathrm{~h}$, the highest PI fluorescence signal gradually increased from $9.57 \%$ to $18.23 \%$ before reaching $28.63 \%$ as the concentration of FPKc was set increasingly from 0, 80, and $120 \mu \mathrm{g} / \mathrm{mL}$ (Fig. 4).

\section{SEM observation}

The cellular morphological effect of FPKc was observed by SEM (Fig. 5). In the control group, the cells appeared with their normal round shape and intact membrane with abundant microvilli. In contrast, cells treated with $80 \mu \mathrm{g} / \mathrm{mL}$ for $24 \mathrm{~h}$ slightly shrunk and the number of microvilli decreased slightly. At a FPKc concentration of $120 \mu \mathrm{g} / \mathrm{mL}$, the cell 


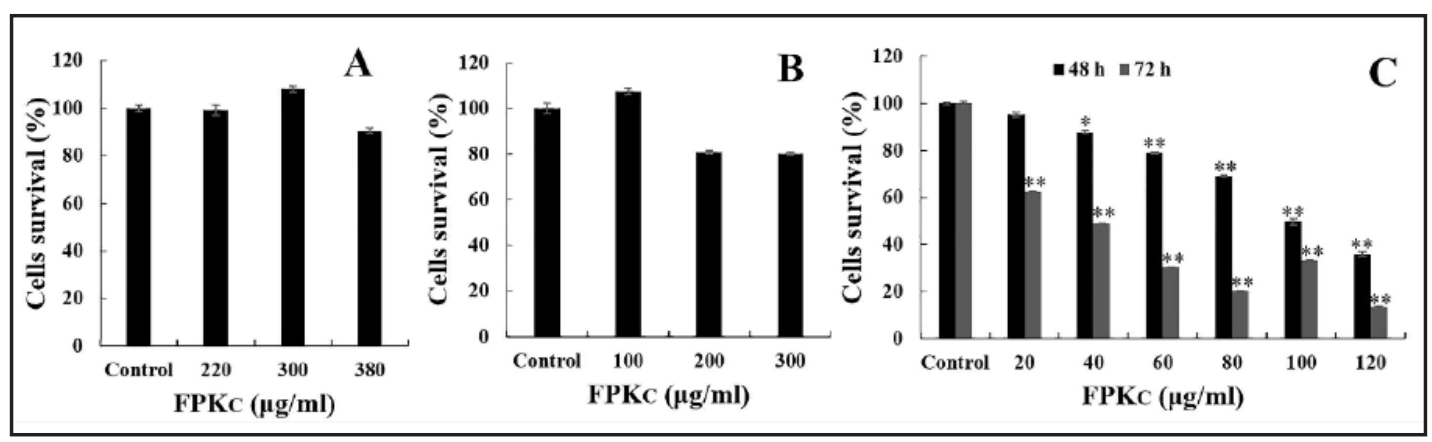

Fig. 3. Safety evaluation for FPKc. HUVEC (A) cells viability after FPKc treatment was measured by MTT assay and PBMC cells (B) viability was evaluated by trypan blue assay. Fig. (C) revealed the cytotoxicity of FPKc on $\mathrm{S} 180$ cells. ${ }^{*} \mathrm{p}<0.05,{ }^{* *} \mathrm{p}<0.01$.

deformation became more significant and the microvilli almost disappeared.

\section{HO-PI double staining}

To determine the type of cell death, HO-PI double staining was used in this study. Nuclear changes associated with apoptosis, such as chromatin condensation and nuclear fragmentation, can be monitored by the dye HO, which stains the nuclei of all cells. Complementary, PI is a dye that reacts positively to the necrotic and late apoptotic cells, but negatively to viable and early apoptotic ones. In combination with fluorescence microscopy,
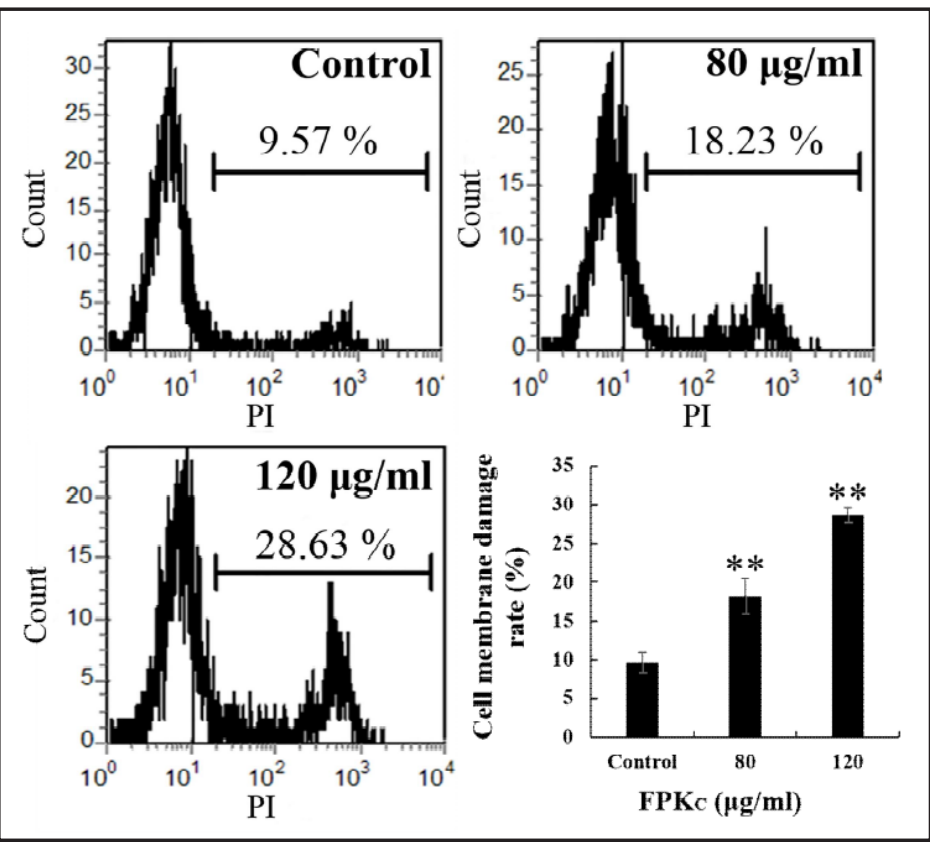

Fig. 4. Effects of FPKc on the cell membrane integrity of S180 cells. selective uptake of the two dyes allows on to distinguish the apoptosis from non-apoptotic cell death (necrosis). In our system, the PI uptake without chromatin condensation or nuclear fragmentation was considered as necrosis $[13,14]$. The pictures in Fig. 6 show the cell morphology changes, revealing that cells shrunk and exhibited abnormal round type of morphology when the S180 cells were treated with $120 \mu \mathrm{g} / \mathrm{mL}$ for $48 \mathrm{~h}$. The results of the $\mathrm{HO}$ staining indicated that the S180 cells were seriously damaged as a bright blue nuclear staining was observed after the FPKc treatment for $48 \mathrm{~h}$. The micrographs shown in Fig. 6 present many S180 cells appearing with a deep HO staining and intense PI staining. These results indicated that the high concentration of FPKc mainly induced late apoptosis at $48 \mathrm{~h}$.

\section{Cell apoptosis induction}

In addition, we detected the apoptosis effect of FPKc with the Annexin V-FITC/PI assay and flow cytometry. To determine whether FPKc exerted a cytotoxicity effect on the S180 cells, we included PS (Phosphatidylserine) translocation experiments that were performed after $24 \mathrm{~h}$ incubation at 80 and $120 \mu \mathrm{g} / \mathrm{mL}$ of FPKc. At this time point, FPKc could induce both early apoptosis and late apoptosis to the S180 cells. Indeed, $21 \%$ of the cells were 


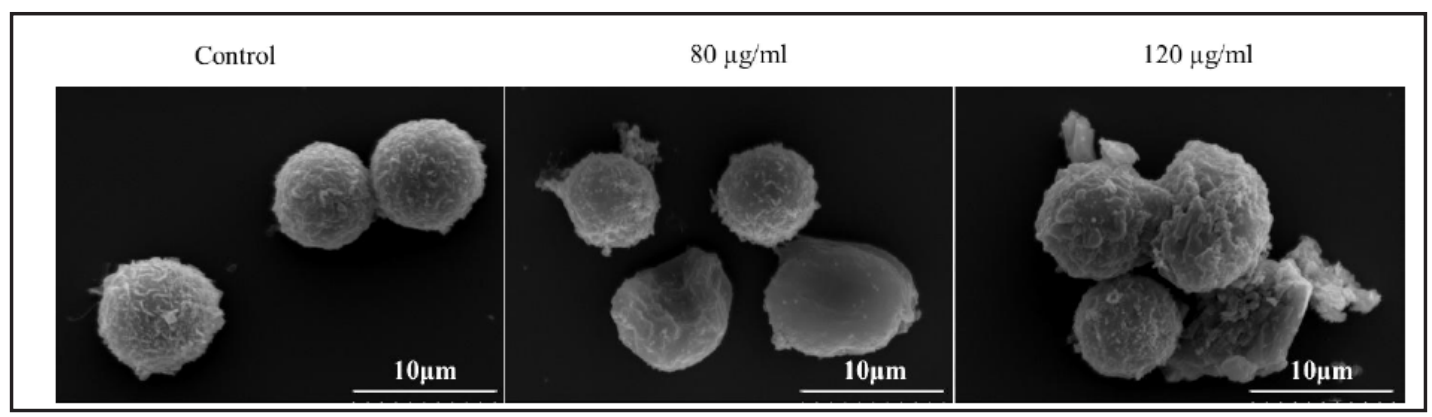

Fig. 5. Scanning electron microscopic images of S180 cells at $24 \mathrm{~h}$ after FPKc treatment.

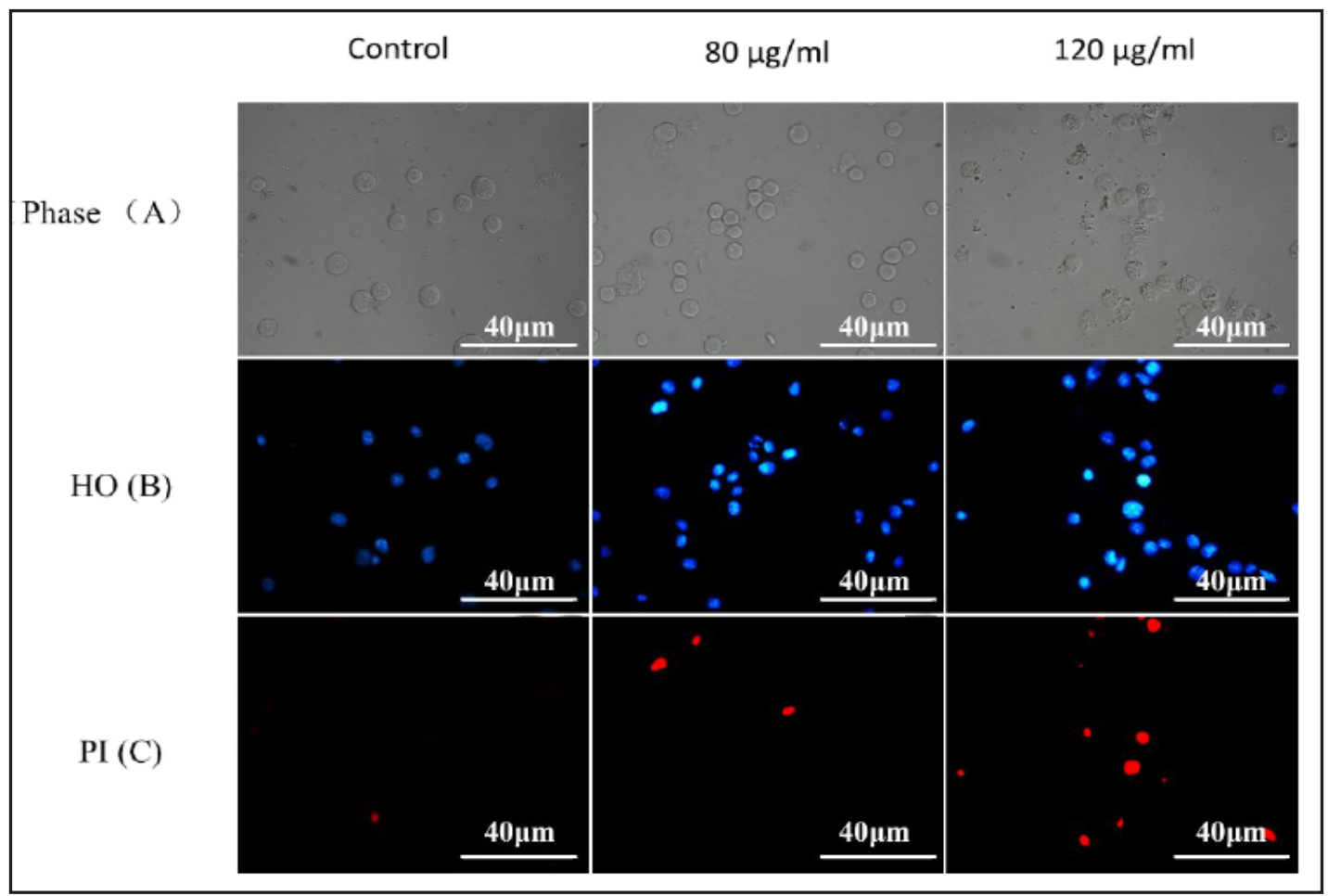

Fig. 6. Apoptosis induced by FPKc was examined by HO-PI staining.

apoptotic when treated with $80 \mu \mathrm{g} / \mathrm{mL}$ of FPKc and 31.4\% of the cells followed apoptosis when $120 \mu \mathrm{g} / \mathrm{mL}$ of FPKc was added. The results revealed that FPKc induced apoptosis in a dose-dependent manner (Fig. 7).

\section{FPKC induced DNA fragmentation}

The PI staining by flow cytometry was used to evaluate the DNA damage caused by FPKc. The results (Fig. 8) revealed that the DNA damage activity increased after an incubation of $24 \mathrm{~h}$ with FPKc in a dose-dependent manner. A FPKc treatment at $80 \mu \mathrm{g} / \mathrm{mL}$ triggered a 1.8fold increase of the DNA damage in the S180 cells, and a FPKc concentration of $120 \mu \mathrm{g} / \mathrm{mL}$ led to a concentration-dependent increase of DNA fragmentation by 3.4-fold, compared to untreated cells $(\mathrm{p}<0.01)$.

\section{Effect of FPKC on cell cycle distribution}

Tumor cells always keep unrestrained cell proliferation because of the gene mutation, which controls cell division. Thus, for treating cancer, cell cycle arrest has been regarded as one of the most important targets [15]. To evaluate the effect of a FPKc treatment on

\section{KARGER}


the distribution of $\mathrm{S} 180$ cells in the cell cycle, we conducted a DNA cell cycle analysis by flow cytometry. The results illustrated in Fig. 9 showed that FPKc could strongly cause the $\mathrm{S}$ phase arrest compared to the control sample and in a dose dependent manner $(\mathrm{p}<0.01)$. The $\mathrm{S}$ values (55.33\% and 64.44\%) obtained at the FPKc respective concentrations of 80 and $120 \mu \mathrm{g} / \mathrm{mL}$ were significantly higher the one of the untreated cells $(49.92 \%)(\mathrm{P}<0.01)$. The differences in the frequency of cells in the G2 phase were imperceptible. The percentage of cells in the G1/S phase for the untreated cells was $46.53 \%$, which was much higher than the ones of the two FPKc-treated groups.

\section{Measurements of MMP changes}

The depletion of MMP is an early marker of the apoptotic process. To determine whether an early loss of MMP occurred during treatment with FPKc in S180 cells, we performed MMP measurement with Rh123 staining. As shown in Fig. 10, the MMP decreased remarkably with increasing concentration of FPKc. The percentage of cells with membrane potential loss increased from $20.53 \%$ to $32.90 \%$ as the concentration of FPKc increased from 80 to 120 $\mu \mathrm{g} / \mathrm{mL}$ at $24 \mathrm{~h}$.

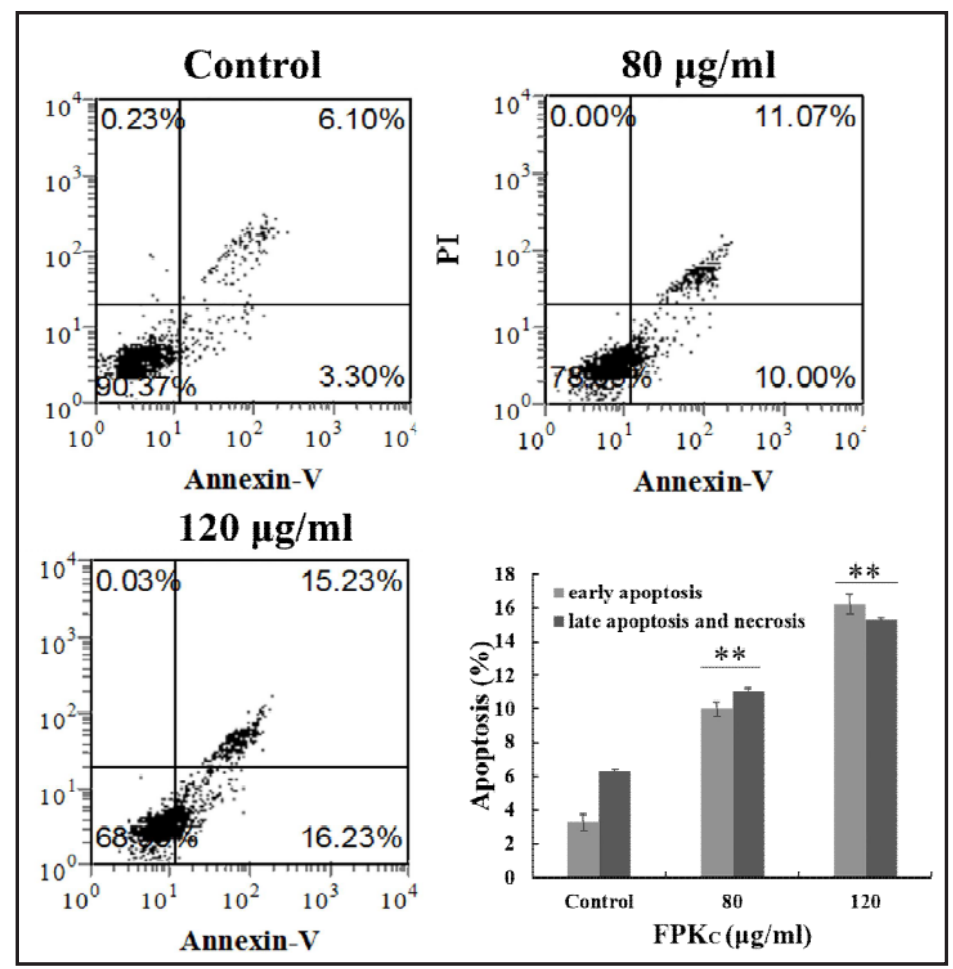

Fig. 7. FPKc induced apoptosis on S180 cells by Annexin V-FITC/PI staining. ${ }^{*} \mathrm{p}<0.05,{ }^{* *} \mathrm{p}<0.01$.

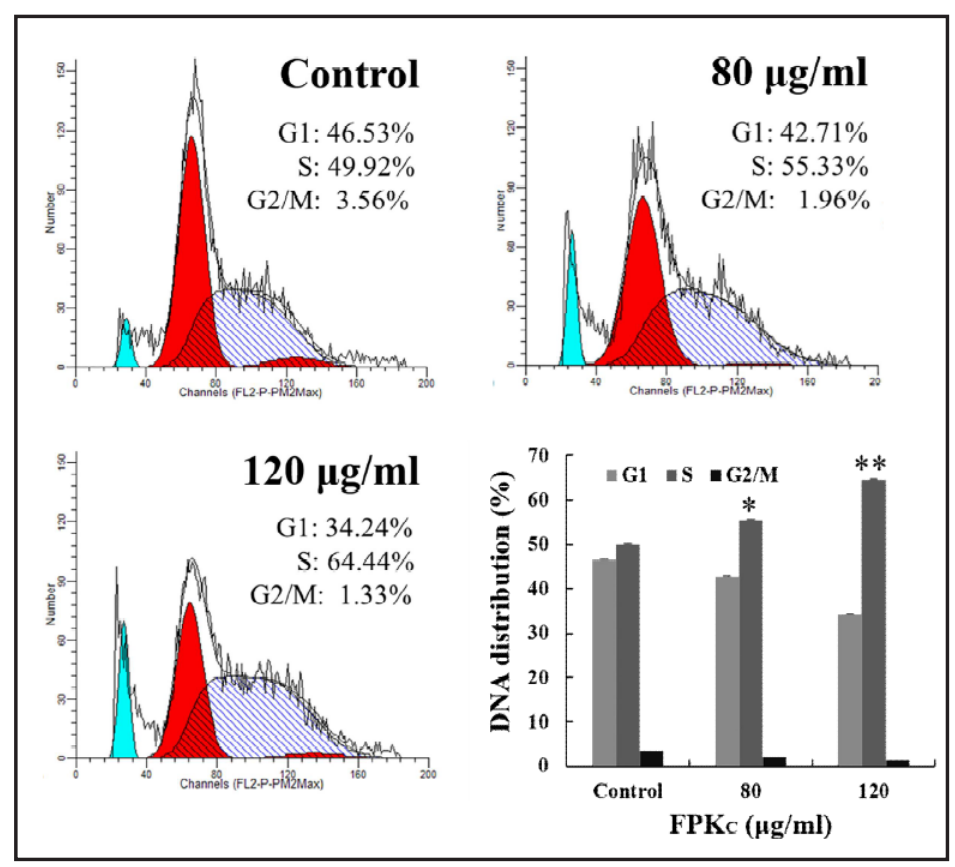

Fig. 8. Effects of FPKc on DNA fragmentation of S180 cells.

\section{Release of cytochrome $C$ detected by immunofluorescence assay}

The Fig. 11 illustrates the cytochrome C release for each group after FPKc treatment. The positions of red fluorescence signals of the cytochrome $C$ overlapped very well with the ones of the green fluorescence of MTG, which was the specific mitochondrial dye used in 
the control cells. At $24 \mathrm{~h}$, the cells treated with $120 \mu \mathrm{g} /$ $\mathrm{mL}$ of FPKc displayed diffuse cytochrome C red fluorescence, whose positions did not overlap very well with the ones of the MTG green fluorescence, implying that cytochrome $\mathrm{C}$ was partially released from the mitochondria.

\section{In-vivo anticancer effect} caused by FPKC

The results depicted in Fig. 12A revealed that FPKc could strongly inhibit the solid tumor in vivo at the inhibition rate of $47.7 \%$ when comparing to the results of the control sample $(\mathrm{p}<0.01)$, which value was close to the CTX group (56.2\%). In addition, the administration of FPKc prolonged the survival time of the S-180 cell-bearing mice as shown in Fig. 12B.

Additionally, the TI, SI, and body weight were calculated to further confirm the non-toxicity of FPKc. The results collected in Table 3 indicate that there was no significant loss of body weight in the group of mice treated with FPKc. From the TI and SI evaluation, we found that the tumor-bearing and CTX groups had a significant decrease in the TI and SI, while increases of both indexes were observed for the FPKc-treated group nearly reaching the value of the normal group. The
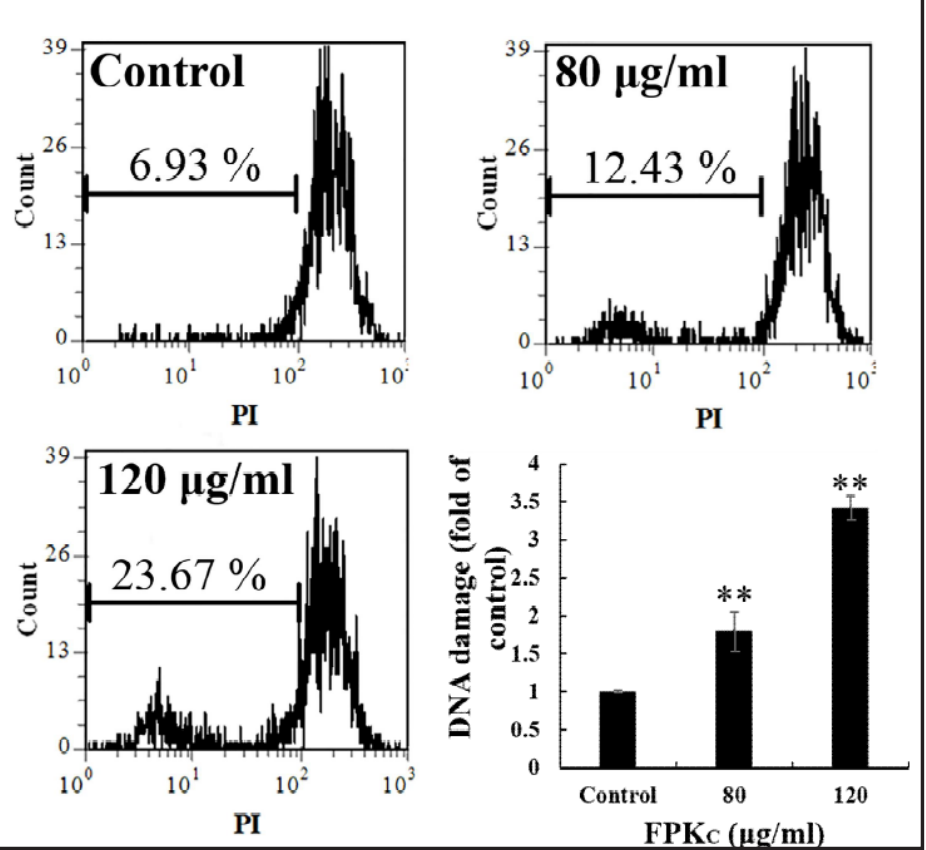

Fig. 9. Cell cycle analysis of FPKc-treated cells by flow cytometer.

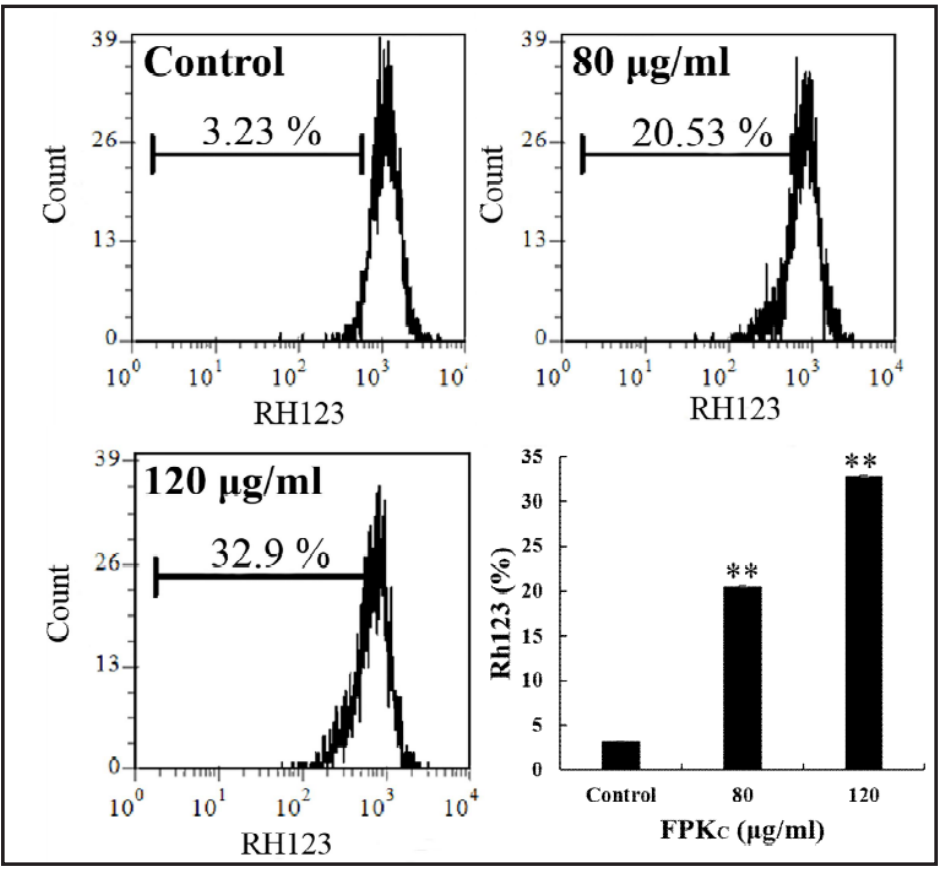

Fig. 10. Effect of FPKc on mitochondrial membrane potential of S180 cells.

had less damage on thymus and spleen than CTX.

\section{Discussion}

The HPLC results revealed that FPKc contains DA, ES, and PA, at $0.25 \%, 10.5 \%$ and $3.56 \%$, respectively. A previous study showed that ES is cytotoxic and has an antitumor activity 


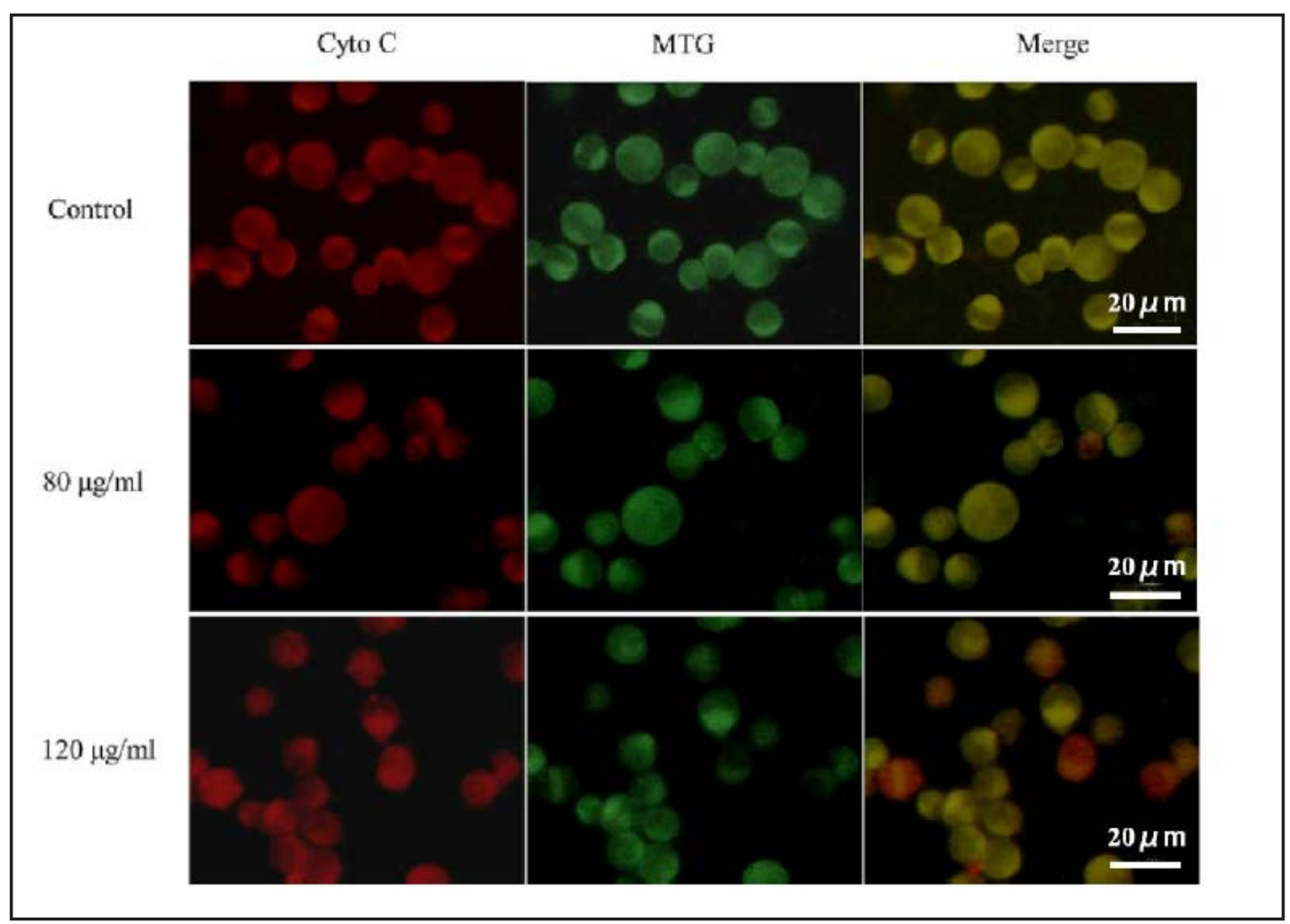

Fig. 11. The release of cytochrome c from mitochondria in S180 cells after FPKc treatment.

Fig. 12. Antitumor effect of FPKc against S180 tumors in vivo (A), Administration of FPKc in S180 tumorbearing mice prolonged the survival time of the mice (B).

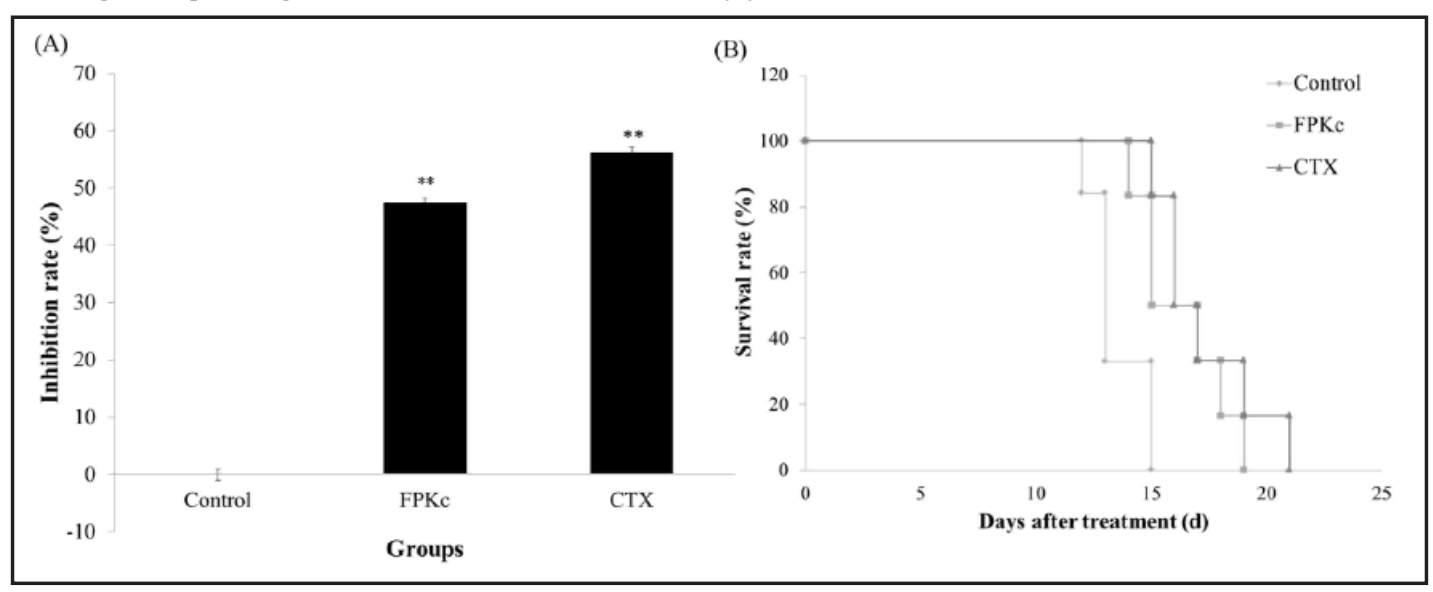

towards several cancers without adverse effects [16]. Moreover, DA and PA are regarded as highly active compounds in some Fomitopsis such as Poria Cocos [17]. More interestingly, PA showed anticancer effect on some tumor cell lines of breast cancer (MDA-MB-231 and MCF-7), prostate cancer (DU145, LNCaP), and human colon carcinoma (HT-29) [18-20]. It is also well documented that DA can provoke DNA damage-induced apoptosis in a dose dependent manner in HL-60 cells [21]. Considering these compounds present in FPKc, we supposed that FPKc could have a cytotoxic activity on cancer cells. In this study, we selected several cell lines, namely SMMC-7721, Eca-109, HL-60, K562, U937, and S180, to evaluate the cytotoxicity of FPKc. The results indicated that FPKc had a general anti-cancer effect on different cancer cell lines at various degrees. Nowadays, natural products are regarded as an

\section{KARGER}


Table 3. Body weight, Thymus index and Spleen index were investigated in the group of mice treated with FPKc

\begin{tabular}{lccc}
\hline Group & Body weight $(\mathrm{mg} /$ per mouse) & Thymus index (\%) & Spleen index (\%) \\
\hline Normal & $28.6 \pm 0.88$ & $2.22 \pm 0.45$ & $7.00 \pm 0.67$ \\
Control & $26.47 \pm 1.13$ & $1.38 \pm 0.63$ & $5.14 \pm 1.40$ \\
FPKc & $27.58 \pm 0.99$ & $2.05 \pm 0.72$ & $5.91 \pm 1.34$ \\
CTX & $23.19 \pm 2.24$ & $1.32 \pm 1.15$ & $5.82 \pm 2.30$ \\
\hline
\end{tabular}

important source of drugs in medicine because of its efficiency and safety. Thus, MTT and a trypan blue assay were applied to evaluate the non-toxicity of FPKc. The in-vitro results indicated that FPKc displayed low toxicity towards normal human cells, which indicated that FPKc was a safe natural product to be further investigated as potential anti-cancer drug.

We found that FPKc inhibited the growth of S180 cells in vitro and in vivo. The in-vivo results showed that a daily dose of $200 \mathrm{mg} / \mathrm{kg}$ of FPKc inhibited the solid tumor growth and prolonged the survival days of the mice, a group behavior that nearly equaled the one of the CTX group $(20 \mathrm{mg} / \mathrm{kg} /$ day). A previous study reported that FPK is extensively used in Asia and Europe as a non-toxic anti-diabetes fungus [4]. Additionally, the little alterations of body weight, SI, and TI further confirmed the low in-vitro cytotoxicity of FPKc on normal cells. Thus, FPKc is actually safe to study and to further develop.

The present study also identified in vitro the mechanisms responsible for the anticancer effect of FPKc on S180 cells. Therefore, we selected a FPKc concentration of $80 \mu \mathrm{g} / \mathrm{mL}$ (approx. $\mathrm{IC}_{30}$ ) and $120 \mu \mathrm{g} / \mathrm{mL}$ (approx. $\mathrm{IC}_{70}$ ) as the test concentrations. To further confirm the growth inhibitory effect induced by FPKc on S180 cells, PI exclusion assay, which was an indicator of irreversible cell death due to cell membrane damage, was used. The results indicated that FPKc could trigger the damage of cell membrane in a dose-dependent manner. In addition, SEM observation confirmed the damage induced by FPKc on S180 cells. The results demonstrated that FPKc could obviously change the cell morphology, leading to cell death.

Cell-cycle dysregulation is the major hallmark of tumor cells [22]. Moreover, cell-cycle arrest is regarded as an important mechanism involved in anti-cancer drug treatment [23]. Our study demonstrated that FPKc could trigger S-phase cell cycle arrest in S180 cells at $72 \mathrm{~h}$ in a dose-independent manner. If this type of arrest cannot be repaired, cells may undergo apoptosis, which is a programmed cell death characterized by DNA degradation, chromatin condensation, and nuclear fragmentation [24]. Deregulation of apoptosis is significant in the initiation and progression of many cancers so that apoptosis induction could be the most promising defense against cancer development [24-28]. In our study, we used HOPI staining and Annexin V-FITC/PI assay to clarify the type of cell death induced by FPKc. The results of both HO-PI staining and Annexin V-FITC/PI assay revealed that FPKc caused late apoptosis in S180 cells after $48 \mathrm{~h}$ treatment; The results of the HO staining evidenced chromatin condensation and micrographs highlighted the damage of the cell morphology, confirming the SEM results. Our previous study demonstrated that FPKc could induce the overexpression of P53 on SW-480 cells, leading to cell apoptosis [29]. The DNA damage is required to increase the P53 level because its ability to bind to DNA increases, mediating the transcriptional activation. Thus the damage could eventually lead to the activation of many genes, resulting in cell-cycle arrest, apoptosis, or DNA repair [30].We detected that FPKc strongly damaged DNA when administered to S180 cells and in a dose-dependent manner. It has been documented that P53 could also down-regulate BCL-2 and up-regulate BAX, which are related to mitochondria mediated apoptosis [31]. Further, several studies reported that apoptosis involves a disruption of the mitochondrial membrane integrity, which is decisive for the cell death process. Moreover, depolarization of the mitochondrial membrane 
potential is a characteristic feature of apoptosis [31,32]. The evaluation of the effects of FPKc on the mitochondrial membrane potential $(\Delta \psi \mathrm{m})$ demonstrated significant MMP loss. The reduction of the membrane potential, the release of mitochondrial cytochrome $\mathrm{C}$, a critical step, is followed by the formation of apoptosomes [33]. Our investigation revealed that at a FPKc concentration of $120 \mu \mathrm{g} / \mathrm{ml}$, the release of mitochondrial cytochrome C was induced, which was in accordance with the published results. Thus, we conclude that FPKc induced S180 cells apoptosis and S-phase cell cycle arrest. In the entire process, mitochondria are strongly suspected to play an important role.

\section{Conclusion}

Native mushroom species recently bear a renewed and increasing interest in the application to modern western medicine. Thus, studying unexplored medicinal potential of European polypore species appears as a promising lead to follow [2]. This is the first study evaluating the anticancer effect of FPK chloroform extract on S180 cells. The FPKc inhibited S180 cells growth and damaged the cell membrane and changed the cell's mophorlogy. Moreover, it triggered in vitro chromatin condensation and DNA damage leading to the S-phase cell cycle arrest and apoptosis. In vivo study demonstrated that FPKc treatment could inhibit the growth of S180 solid tumor and prolong the survival time of tumor-bearing mice.

Chemical analysis determined that FPK was mainly composed of $75 \%$ of triterpenoids. In this study, we selected three of the triterpenoids because they were reported to have an anticancer effect on some cancer cell lines. However, the specific active compounds in FPKc are still not completely identified. Next, we will devote ourselves to find out the functional components and further investigate the specific signal pathways involved in the anti-cancer mechanism of FPKc.

\section{Acknowledgements}

This work was supported by the Natural Science Foundation of Shaanxi Province, China (No. 2017KJXX-78, 2016JM8068) the Fundamental Research Funds for the Central Universities (No. GK201502009, GK201603070), the Academic Leaders and Academic Backbones, Shaanxi Normal University (No. 16QNGG012).

\section{Disclosure Statement}

The authors declare no conflict of interest.

\section{References}

1 Rosecke J, Pietsch M, Konig WA: Volatile constituents of wood-rotting basidiomycetes. Phytochemistry 2000;54:747-750.

2 Grienke U, Zoll M, Peintner U, Rollinger JM: European medicinal polypores-a modern view on traditional uses. J Ethnopharmacol 2014;154:564-583.

3 Yoshikawa K, Inoue M, Matsumoto Y, Sakakibara C, Miyataka H, Matsumoto H, Arihara S: Lanostane triterpenoids and triterpene glycosides from the fruit body of fomitopsis pinicola and their inhibitory activity against cox-1 and cox-2. J Nat Prod 2005;68:69-73.

-4 Lee SI, Kim JS, Oh SH, Park KY, Lee HG, Kim SD: Antihyperglycemic effect of fomitopsis pinicola extracts in streptozotocin-induced diabetic rats. J Med Food 2008;11:518-524. 


\section{Cellular Physiology Cell Physiol Biochem 2017;44:2042-2056 \begin{tabular}{l|l} 
DOI: 10.1159/000485944 & $\begin{array}{l}\text { O 2017 The Author(s). Published by S. Karger AG, Basel } \\
\text { www.karger.com/cpb }\end{array}$ \\
\hline
\end{tabular}

5 Rosecke J, Konig WA: Steroids from the fungus fomitopsis pinicola. Phytochemistry 1999;52:1621-1627.

6 Keller AC, Maillard MP, Hostettmann K: Antimicrobial steroids from the fungus fomitopsis pinicola. Phytochemistry 1996;41:1041-1046.

7 Ren G, Liu XY, Zhu HK, Yang SZ, Fu CX: Evaluation of cytotoxic activities of some medicinal polypore fungi from china. Fitoterapia 2006;77:408-410.

-8 Wu HT, Lu FH, Su YC, Ou HY, Hung HC, Wu JS, Yang YC, Chang CJ: In vivo and in vitro anti-tumor effects of fungal extracts. Molecules 2014;19:2546-2556.

-9 Cheng X, Xiao Y, Wang X, Wang P, Li H, Yan H, Liu Q: Anti-tumor and pro-apoptotic activity of ethanolic extract and its various fractions from polytrichum commune l.Ex hedw in 1210 cells. J Ethnopharmacol 2012;143:49-56.

10 Kim A, Im M, Ma JY: Srvf, a novel herbal formula including scrophulariae radix and viticis fructus, disrupts focal adhesion and causes detachment-induced apoptosis in malignant cancer cells. Sci Rep 2017;7:12756.

11 Siegel R, Naishadham D, Jemal A: Cancer statistics, 2013. CA Cancer J Clin 2013;63:11-30.

12 Becker MS, Schmezer P, Breuer R, Haas SF, Essers MA, Krammer PH, Li-Weber M: The traditional chinese medical compound rocaglamide protects nonmalignant primary cells from DNA damage-induced toxicity by inhibition of p53 expression. Cell Death Dis 2014;5:e1000.

13 Grusch M, Fritzer-Szekeres M, Fuhrmann G, Rosenberger G, Luxbacher C, Elford HL, Smid K, Peters GJ, Szekeres T, Krupitza G: Activation of caspases and induction of apoptosis by novel ribonucleotide reductase inhibitors amidox and didox. Exp Hematol 2001;29:623-632.

14 Emirdag-Ozturk S, Babahan I, Ozmen A: Synthesis, characterization and in vitro anti-neoplastic activity of gypsogenin derivatives. Bioorg Chem 2014;53:15-23.

15 Li L, Lu N, Dai Q, Wei L, Zhao Q, Li Z, He Q Dai Y, Guo Q: Gl-v9, a newly synthetic flavonoid derivative, induces mitochondrial-mediated apoptosis and g2/m cell cycle arrest in human hepatocellular carcinoma hepg2 cells. Eur J Pharmacol 2011;670:13-21.

-16 Yazawa Y, Yokota M, Sugiyama K: Antitumor promoting effect of an active component of polyporus, ergosterol and related compounds on rat urinary bladder carcinogenesis in a short-term test with concanavalin a. Biol Pharm Bull 2000;23:1298-1302.

17 Lee JH, Lee YJ, Shin JK, Nam JW, Nah SY, Kim SH, Jeong JH, Kim Y, Shin M, Hong M, Seo EK, Bae H: Effects of triterpenoids from poria cocos wolf on the serotonin type 3a receptor-mediated ion current in xenopus oocytes. Eur J Pharmacol 2009;615:27-32.

18 Hong R, Shen MH, Xie XH, Ruan SM: Inhibition of breast cancer metastasis via pitpnm3 by pachymic acid. Asian Pac J Cancer Prev 2012;13:1877-1880.

19 Gapter L, Wang Z, Glinski J, Ng KY: Induction of apoptosis in prostate cancer cells by pachymic acid from poria cocos. Biochem Biophys Res Commun 2005;332:1153-1161.

-20 Ling H, Zhang Y, Ng KY, Chew EH: Pachymic acid impairs breast cancer cell invasion by suppressing nuclear factor-kappab-dependent matrix metalloproteinase-9 expression. Breast Cancer Res Treat 2011;126:609620.

-21 Du YC, Chang FR, Wu TY, Hsu YM, El-Shazly M, Chen CF, Sung PJ, Lin YY, Lin YH, Wu YC, Lu MC: Antileukemia component, dehydroeburicoic acid from antrodia camphorata induces DNA damage and apoptosis in vitro and in vivo models. Phytomedicine 2012;19:788-796.

-22 Wang J, Wu A, Xu Y, Liu J, Qian X: M(2)-a induces apoptosis and g(2)-m arrest via inhibiting pi3k/akt pathway in hl60 cells. Cancer Lett 2009;283:193-202.

-23 Xiao XY, Hao M, Yang XY, Ba Q, Li M, Ni SJ, Wang LS, Du X: Licochalcone a inhibits growth of gastric cancer cells by arresting cell cycle progression and inducing apoptosis. Cancer Lett 2011;302:69-75.

24 Thompson CB: Apoptosis in the pathogenesis and treatment of disease. Science 1995;267:1456-1462.

25 Tang X, Huang J, Xiong H, Zhang K, Chen C, Wei X, Xu X, Xie Q, Huang R: Anti-tumor effects of the polysaccharide isolated from tarphochlamys affinis in h22 tumor-bearing mice. Cell Physiol Biochem 2016;39:1040-1050.

26 Korsmeyer SJ: Chromosomal translocations in lymphoid malignancies reveal novel proto-oncogenes. Annu Rev Immunol 1992;10:785-807.

27 Li H, Wang P, Liu Q Cheng X, Zhou Y, Xiao Y: Cell cycle arrest and cell apoptosis induced by equisetum hyemale extract in murine leukemia 11210 cells. J Ethnopharmacol 2012;144:322-327. 


\section{Cellular Physiology Cell Physiol Biochem 2017;44:2042-2056 \begin{tabular}{l|l|l} 
and Biochemistry & $\begin{array}{l}\text { DOI: 10.1159/000485944 } \\
\text { Published online: December 12, } 2017\end{array}$ & $\begin{array}{l}\text { O 2017 The Author(s). Published by S. Karger AG, Basel } \\
\text { www.karger.com/cpb }\end{array}$ \\
\cline { 2 - 3 }
\end{tabular} \\ Gao et al.: FPKc Extract against S180 Tumor Cells}

28 Wang Y, Cheng X, Wang P, Wang L, Fan J, Wang X, Liu Q: Investigating migration inhibition and apoptotic effects of fomitopsis pinicola chloroform extract on human colorectal cancer sw-480 cells. PLoS One 2014;9:e101303.

29 Hafeez BB, Siddiqui IA, Asim M, Malik A, Afaq F, Adhami VM, Saleem M, Din M, Mukhtar H: A dietary anthocyanidin delphinidin induces apoptosis of human prostate cancer pc3 cells in vitro and in vivo: Involvement of nuclear factor-kappab signaling. Cancer Res 2008;68:8564-8572.

30 Li Y, Liu J, Li Q: Mechanisms by which the antitumor compound di-n-butyl-di-(4-chlorobenzohydroxamato) tin(iv) induces apoptosis and the mitochondrial-mediated signaling pathway in human cancer sgc-7901 cells. Mol Carcinog 2010;49:566-581.

-31 Huang YT, Huang YH, Hour TC, Pan BS, Liu YC, Pan MH: Apoptosis-inducing active components from corbicula fluminea through activation of caspase- 2 and production of reactive oxygen species in human leukemia hl-60 cells. Food Chem Toxicol 2006;44:1261-1272.

32 Nunes C, Barbosa RM, Almeida L, Laranjinha J: Nitric oxide and dopac-induced cell death: From gsh depletion to mitochondrial energy crisis. Mol Cell Neurosci 2011;48:94-103.

-33 Pieme CA, Guru SK, Ambassa P, Kumar S, Ngameni B, Ngogang JY, Bhushan S, Saxena AK: Induction of mitochondrial dependent apoptosis and cell cycle arrest in human promyelocytic leukemia hl-60 cells by an extract from dorstenia psilurus: A spice from cameroon. BMC Complement Altern Med 2013;13:223. 